\title{
Spatial and Temporal Structures of the Macrozoobenthos from the Intertidal Zone of the Kneiss Islands (Central Mediterranean Sea)
}

\author{
Nawfel Mosbahi ${ }^{*}$, Jean-Philippe Pezy ${ }^{2}$, Jean-Claude Dauvin², Lassad Neifar ${ }^{1}$ \\ ${ }^{1}$ Laboratoire de Biodiversité et Ecosystèmes Aquatiques, Faculté des Sciences de Sfax, Université de Sfax, Sfax, \\ Tunisie \\ ${ }^{2}$ CNRS UMR 6143 M2C, Laboratoire Morphodynamique Continentale et Côtière, Université de Caen Normandie, \\ UNICAEN, Caen, France \\ Email: "nawfelmosbahi@hotmail.fr
}

Received 26 February 2016; accepted 8 April 2016; published 11 April 2016

Copyright $@ 2016$ by authors and Scientific Research Publishing Inc.

This work is licensed under the Creative Commons Attribution International License (CC BY).

http://creativecommons.org/licenses/by/4.0/

(c) (i) Open Access

\section{Abstract}

The present study analyses the spatio-temporal variability of the macrozoobenthos from the intertidal zone of the Kneiss Islands (Gulf of Gabès, Tunisia). Samples were collected once from 34 stations, while seasonal variations were studied by sampling four times at 12 stations over the period 2013-2014. A total of 159 macrobenthos taxa associated with intertidal Zostera noltei beds are identified from the 34 stations, with a taxonomic dominance of crustaceans $(32 \%)$, molluscs (29\%) and annelids (27\%). Abundance varies from 9244 to 36,844 ind $\cdot \mathrm{m}^{-2}$ with a mean value of $14,346 \mathrm{ind} \cdot \mathrm{m}^{-2}$. Analysis of the trophic structure shows that the majority of stations are strongly represented by carnivores $(41 \%)$, followed by the non-selective deposit feeders $(16 \%)$. Cluster analysis and multidimensional scaling allow identification of three main benthic assemblages based on species abundance, corresponding to different sediment types and organic matter contents. The seasonal variability in abundance, diversity and community structure is mainly due to spring and summer recruitment. The biotic indices (i.e. AMBI, BO2A and BENTIX) show that the intertidal area of Kneiss Islands exhibits a good ecological status.

\section{Keywords}

Kneiss Islands, Zostera noltei, Spatial Distribution, Seasonal Variability, Benthic Macrofauna

\footnotetext{
${ }^{*}$ Corresponding author.

How to cite this paper: Mosbahi, N., Pezy, J.-P., Dauvin, J.-C. and Neifar, L. (2016) Spatial and Temporal Structures of the Macrozoobenthos from the Intertidal Zone of the Kneiss Islands (Central Mediterranean Sea). Open Journal of Marine Science, 6, 223-237. http://dx.doi.org/10.4236/ojms.2016.62018
} 


\section{Introduction}

Owing to their position at the interface of land and sea, shallow waters and coastal areas are generally highly productive and ecologically important [1] [2]. However, coastal ecosystems often form a mosaic of interlinked habitats that should not be considered in isolation. Each habitat has its own characteristics and hosts particular benthic assemblages [3]-[5]. Nevertheless, coastal habitats are threatened by anthropogenic stressors, including coastal development and habitat degradation [6]-[9]. Indeed, many human activities (pollution, tourism, clam harvesting, bait digging, commercial fisheries, eutrophication, sediment discharge, sand extraction and marine transportation) have directly and indirectly affected the biodiversity of these ecosystems on a worldwide scale [10]-[13]. As a result, many species and habitats are in jeopardy [14], considering that degradation has modified coastal habitats to such a degree that they no longer fulfill their functional roles as nurseries, in feeding or in reproduction [15] [16].

In Tunisia, very few studies have been carried out on intertidal benthic macrofauna. Nevertheless, the macrobenthos of the Gulf of Gabès has been relatively more studied [17]. It is known that the benthic macrofauna is an important component in marine ecosystems, playing a vital role in nutrient cycling, detrital decomposition and as a food source for higher trophic levels. Due to their relatively sessile habit, which implies the inability to avoid unfavourable conditions, macrobenthic species are sensitive indicators of changes in marine environments caused by natural stress or anthropogenic disturbances [13] [18] [19]. As benthic species are relatively longlived, they integrate water and sediment quality conditions over time, thus indicating temporal as well as chronic disturbances; consequently, macrofauna can be used as a powerful tool to detect even slight environmental changes [20] [21].

Moreover, the Kneiss Islands, located in the Gulf of Gabès (central Mediterranean Sea), represent a site of international interest in terms of their ornithological diversity (Important Bird area, SPAMI, and Ramsar site), with over 330,000 water birds counted on this wetland in spring [22]. This avifaunal biodiversity is closely related to the benthic communities which play a crucial role in the food web either by feeding on detritus, or as food for aquatic birds [23] [24].

Likewise, the marine ecosystems of the Kneiss Islands in the Gulf of Gabès are subject to the loss and degradation of biodiversity caused by bottom trawling [25] [26], clam harvesting [27], bait digging [28] and pollution due to various anthropogenic activities linked to the phosphate industry [29]. In addition, discharges to the sea are rendering the Skhira harbour environment hostile for native species and favouring the proliferation of invasive species (both native and non-native) [30], which represent a possible threat due to climate change [31].

Mosbahi et al. (2015) presented a first description of the intertidal macrozoobenthic communities in a small part of the Kneiss Islands. By extending this previous research, the present study investigates the spatial and seasonal structure of the macrobenthic communities of a large area around the Kneiss Islands over a 2-yearcycle. The main aims are: 1 ) to investigate the structural diversity of the benthic macrofauna based on taxonomic, trophic groups and the biodiversity parameters of the benthic macrofauna; 2) to identify the role of the main environmental factors that determine the benthic community structure and functioning; and 3) to provide a reliable assessment of the general ecological status of the macrobenthos.

\section{Materials and Methods}

\subsection{Study Area}

Located in the north-western part of the Gulf of Gabès, between latitudes $34^{\circ} 10^{\prime} \mathrm{N}-34^{\circ} 30^{\prime} \mathrm{N}$ and longitudes $10^{\circ} \mathrm{E}-10^{\circ} 30^{\prime} \mathrm{E}$, the intertidal zone around the Kneiss Islands extends over an area of $220 \mathrm{~km}^{2}$ (Figure 1). This area is characterized by the highest tidal range in the western Mediterranean Sea; the tide is semi-diurnal with an amplitude varying from 0.8 to $2.3 \mathrm{~m}$ [32]. At low tide, the Kneiss Islands are surrounded by vast mud and sand flats [33], making this site the most important area for wintering of migratory waders in the Mediterranean region.

Due to the high biodiversity of benthic communities, the foreshore of the Kneiss Islands represents the largest area in terms of water bird conservation in the Mediterranean zone (Important Bird Area in 2003) and has been designated a Ramsar site since 2007. Moreover, the tidal flats of Kneiss Islands are colonized by seagrass meadows composed of Zostera noltei Hornemann [17]. 


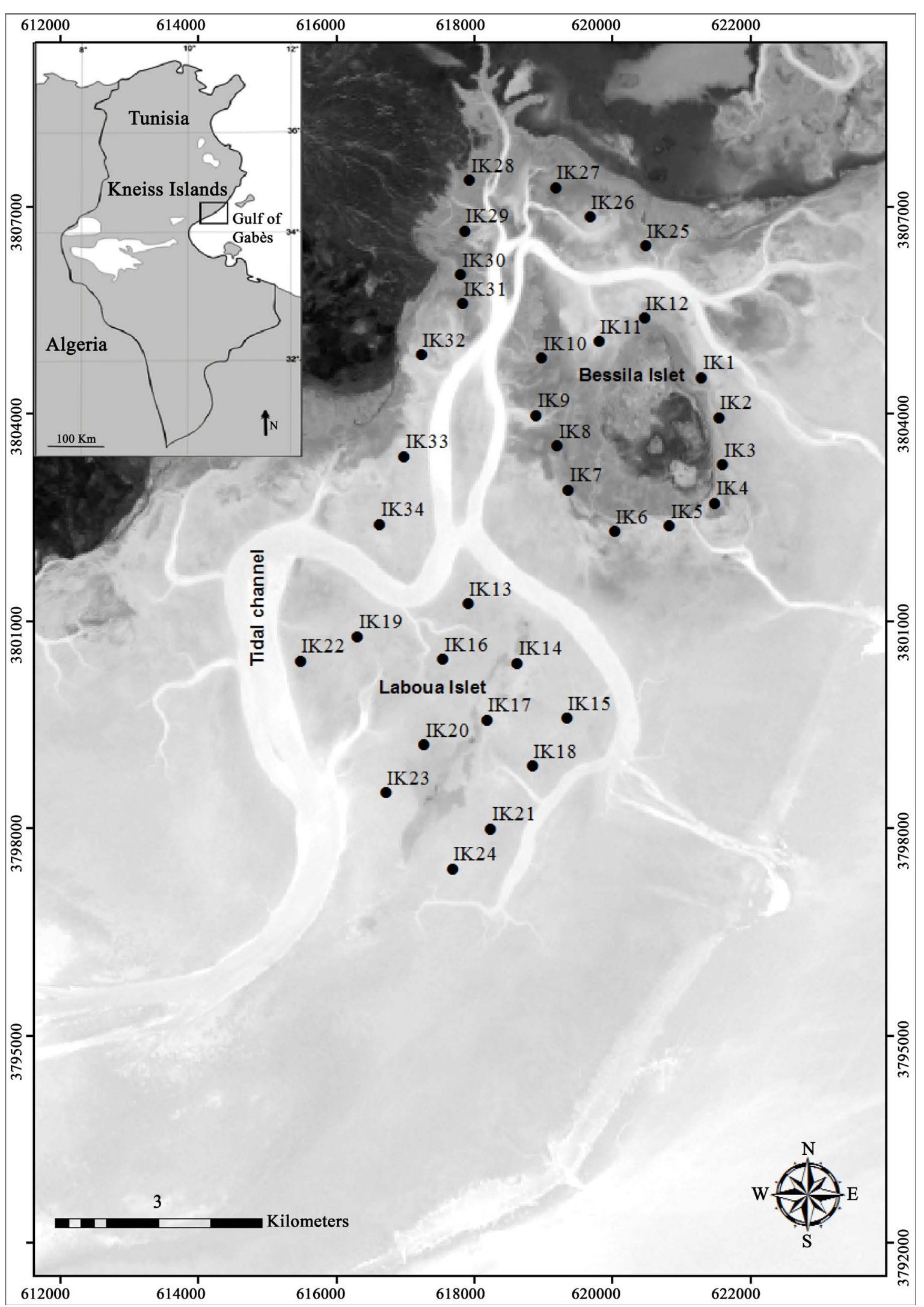

Figure 1. Map of study area showing location of sampling stations. 


\subsection{Sampling and Laboratory Procedures}

\subsubsection{Macrofauna}

Samples of the macrobenthic macrofauna were collected at low tide using a corer with a sampling area of 0.0225 $\mathrm{m}^{2}$. Five replicates were carried out at each station, with four samples for biological analysis covering a total surface-area of $0.09 \mathrm{~m}^{2}$, and one sample for sediment analysis. Sampling consisted of collecting the topmost 20 $\mathrm{cm}$ of the sediment, being carried out at 34 stations in April 2014, in areas corresponding to fully extended Zostera noltei seagrass beds (Figure 1). Moreover, to identify the seasonal changes in macrofauna diversity, 12 stations around the Bessila islet were sampled four times (in October 2013, and in January, April and July 2014).

Sediment was sieved through a 1-mm mesh; the remaining fraction was fixed in $4 \%$ buffered formalin and stained with Rose Bengale. In the laboratory, macrofauna was sorted, identified when possible to the species level under the stereomicroscope, and counted. Species number corresponds to the total number of species recorded in $0.09 \mathrm{~m}^{2}$, and abundance to the number of individuals per $1 \mathrm{~m}^{2}$.

\subsubsection{Sediment Analysis}

The topmost 3-cm sediment layer was also sampled in each replicate for granulometric analysis (median grainsize). Median grain size was determined after sieving the weighed and dried sediment through a wet column of sieves with decreasing apertures $(1000,500,250,125$ and $63 \mu \mathrm{m})$. Sediment samples were then dried at $80^{\circ} \mathrm{C}$ to constant weight and ground to a fine powder. The organic matter (OM) content was determined on the powder samples by "loss on ignition" at $450^{\circ} \mathrm{C}$ for 4 hrs. Heavy metal contents ( $\mathrm{Zn}, \mathrm{Pb}, \mathrm{Cd}, \mathrm{Fe}$ and $\mathrm{P}$ ) were estimated after digesting the powder sample in aqua regia $\left(\mathrm{HCl}^{-}, \mathrm{HNO}_{3}^{-}, \mathrm{H}_{2} \mathrm{O}\right)$ at $95^{\circ} \mathrm{C}$, and analysis by Inductively Coupled Plasma Atomic Emission Spectrometry (ICP-AES) and Mass Spectrometry (ICP-MS) [34].

\subsection{Data Analysis}

\subsubsection{Biotic Indices}

The original data analyzed here consists of a "stations $\times$ species" matrix (34 stations $\times 125$ species), which was obtained after removing rare species (29 species). Species were considered rare when they occurred at less than three stations. Abundances were square-root transformed prior to analysis.

Benthic macrofauna communities are defined quantitatively by selected descriptors which reflect the numerical importance of the species. Specific richness S (number of species in each station), abundance A (ind $\cdot \mathrm{m}^{-2}$ ), Shannon-Weaver's diversity index H' [35] and Pielou's evenness (J') [36] are calculated at each station (Table 1). The values of the index of Shannon-Weaver diversity is interpreted according to the limits set by [37] used in France as part of the Water Framework Directive (WFD) for coastal areas.

Identified species are classified here into trophic groups according to [38] and later modified by [1] [39]-[42]. Three currently available univariate Biotic Indices (BIs) are tested, namely AMBI. BENTIX and BO2A. AMBI (AZTI Marine Biotic Index) based on the study of [39], which considers five ecological groups ranging from sensitive species (EGI) to first-order opportunistic species (EGV) [43]. BENTIX considers only two groups: sensitive (GS) and tolerant species (GT), which correspond to ecological groups I and II, and to ecological groups III to V of the AMBI, respectively [44] [45]. The BO2A (Benthic Opportunistic Polychaete Amphipod index) is based on the ratio of opportunistic polychaetes (i.e. polychaetes of ecological groups IV and $\mathrm{V}$ of the AMBI) and amphipods (except for the genus Jassa) [46] [47].

\subsubsection{Univariate Analysis}

Regarding the seasonal parameters (Table 2), a Shapiro-Wilk normality test and a Bartlett's test for homogeneity of variance are performed prior to each ANOVA to check whether the assumptions of ANOVA are met and if data transformation is necessary. Then, ANOVAs are performed to assess the influence of the seasons (winter, spring, summer and autumn) on benthic abundance, taxonomic richness, organic matter, temperature, salinity and $\mathrm{pH}$. A Tukey Honestly Significant Difference test is used to determine differences between the four seasons. The same analyses are performed to assess the difference in organic matter between the three sediment types.

\subsubsection{Multivariate Analysis}

Multivariate analysis is performed to study spatial variability of the macrozoobenthic communities associated with Zostera (Zosterella) noltei seagrass. A square root transformation is applied to the abundance matrix (data 
for each station are pooled prior to undertaking further analyses), before calculating the Bray-Curtis similarities using the statistical package PRIMER ${ }^{\circledR} 6.0$ [48]. A dendrogram is thus created, with group averages expressed in the cluster mode. Then, a non-parametric multi-dimensional scaling (MDS) ordination, using the Bray-Curtis similarity measure, is applied to the abundance matrix (after square-root transformation), with the objective of examining the spatial variability of macrozoobenthic communities. The SIMilarity PERcentages (SIMPER) routine is used to establish which species contribute most to the observed differences in the data.

Table 1. Main characteristics of sampling stations and macrofauna collected during spring (April) 2014. S: species richness; A: Abundance (ind $\cdot \mathrm{m}^{-2}$ ), H': Shannon-Weaner diversity index; J': Pielou's evenness index; AMBI values, BO2A values, BENTIX values; T: Temperature $\left({ }^{\circ} \mathrm{C}\right)$; Sal: salinity; $\mathrm{pH}$; OM: organic matter $\left(\mathrm{g} \cdot \mathrm{kg}^{-1}\right)$; Sed: sediment; FS: fine sand; MS: medium sand; mud; Long E: longitude east; Lat N: latitude north.

\begin{tabular}{|c|c|c|c|c|c|c|c|c|c|c|c|c|c|c|}
\hline Stations & Long E & Lat $\mathrm{N}$ & Sed & S & A & J' & $\mathrm{H}^{\prime}$ & AMBI & $\mathrm{BO} 2 \mathrm{~A}$ & BENTIX & $\mathrm{T}^{\circ} \mathrm{C}$ & Sal & $\mathrm{pH}$ & $\mathrm{OM}$ \\
\hline IK1 & $32.621306^{\circ}$ & $38.04531^{\circ}$ & FS & 27 & 17,600 & 0.87 & 4.14 & 1.18 & 0.003 & 4.65 & 23.4 & 39.2 & 8.69 & 1.59 \\
\hline IK2 & $32.621554^{\circ}$ & $38.03952^{\circ}$ & MS & 24 & 12,977 & 0.80 & 3.67 & 1.77 & 0.037 & 4.04 & 23.5 & 39.3 & 8.69 & 2.43 \\
\hline IK3 & $32.621609^{\circ}$ & $38.03262^{\circ}$ & FS & 29 & 13,377 & 0.90 & 4.37 & 1.57 & 0.001 & 4.97 & 23.8 & 39.5 & 8.67 & 1.34 \\
\hline IK4 & $32.621499^{\circ}$ & $38.02711^{\circ}$ & FS & 22 & 12,133 & 0.84 & 3.76 & 0.46 & 0.001 & 5.52 & 23.8 & 39.7 & 8.67 & 1.32 \\
\hline IK5 & $32.620837^{\circ}$ & $38.02380^{\circ}$ & FS & 39 & 22,444 & 0.86 & 4.57 & 1.54 & 0.047 & 4.42 & 23.9 & 39.3 & 8.67 & 2.28 \\
\hline IK6 & $32.620037^{\circ}$ & $38.02297^{\circ}$ & FS & 36 & 14,888 & 0.87 & 4.54 & 1.93 & 0.064 & 4.22 & 23.2 & 39.6 & 8.64 & 3.23 \\
\hline IK7 & $32.619375^{\circ}$ & $38.02904^{\circ}$ & FS & 35 & 36,844 & 0.68 & 3.53 & 1.88 & 0.001 & 3.97 & 22.9 & 39.2 & 8.64 & 2.03 \\
\hline IK8 & $32.619209^{\circ}$ & $38.03538^{\circ}$ & FS & 25 & 11,422 & 0.90 & 4.18 & 1.75 & 0.067 & 4.08 & 22.8 & 39.5 & 8.65 & 2.52 \\
\hline IK9 & $32.618906^{\circ}$ & $38.03980^{\circ}$ & FS & 28 & 13,111 & 0.88 & 4.23 & 1.20 & 0.036 & 5.04 & 22.8 & 39.2 & 8.59 & 2.85 \\
\hline IK10 & $32.618989^{\circ}$ & $38.04807^{\circ}$ & FS & 31 & 11,733 & 0.88 & 4.37 & 1.67 & 0.012 & 4.39 & 22.9 & 39.2 & 8.65 & 1.43 \\
\hline IK11 & $32.619816^{\circ}$ & $38.05055^{\circ}$ & MS & 22 & 12,755 & 0.87 & 3.91 & 2.18 & 0.067 & 3.58 & 22.7 & 39.2 & 8.71 & 1.84 \\
\hline IK12 & $32.620478^{\circ}$ & $38.05387^{\circ}$ & FS & 34 & 14,622 & 0.89 & 4.53 & 1.35 & 0.046 & 4.71 & 23.2 & 39.3 & 8.64 & 3.66 \\
\hline IK13 & $32.617913^{\circ}$ & $38.01249^{\circ}$ & MS & 30 & 10,355 & 0.86 & 4.22 & 1.43 & 0.045 & 4.71 & 23.8 & 39.5 & 8.05 & 2.54 \\
\hline IK14 & $32.618630^{\circ}$ & $38.00393^{\circ}$ & MS & 33 & 9800 & 0.87 & 4.40 & 1.52 & 0.006 & 4.55 & 22.8 & 39.4 & 8.26 & 1.85 \\
\hline IK15 & $32.619347^{\circ}$ & $37.99593^{\circ}$ & MS & 33 & 10,622 & 0.81 & 4.08 & 1.45 & 0.033 & 4.98 & 22.8 & 39.5 & 8.36 & 4.32 \\
\hline IK16 & $32.617554^{\circ}$ & $38.00449^{\circ}$ & MS & 37 & 10,711 & 0.88 & 4.60 & 1.29 & 0.050 & 5.24 & 23.1 & 39.5 & 8.40 & 3.25 \\
\hline IK17 & $32.618189^{\circ}$ & $37.99566^{\circ}$ & MS & 32 & 9511 & 0.88 & 4.40 & 1.92 & 0.050 & 4.24 & 23.3 & 39.5 & 8.49 & 2.92 \\
\hline IK18 & $32.618851^{\circ}$ & $37.98904^{\circ}$ & MS & 30 & 10,222 & 0.92 & 4.53 & 1.43 & 0.042 & 4.67 & 23.2 & 39.5 & 8.54 & 3.94 \\
\hline IK19 & $32.616313^{\circ}$ & $38.00780^{\circ}$ & MS & 38 & 11,800 & 0.85 & 4.49 & 1.83 & 0.044 & 4.17 & 23.1 & 39.5 & 8.55 & 1.75 \\
\hline IK20 & $32.617278^{\circ}$ & $37.99207^{\circ}$ & MS & 38 & 10,000 & 0.90 & 4.76 & 1.23 & 0.041 & 5.14 & 23.3 & 39.5 & 8.53 & 3.61 \\
\hline IK21 & $32.618244^{\circ}$ & $37.97993^{\circ}$ & MS & 36 & 9244 & 0.82 & 4.25 & 1.77 & 0.008 & 4.20 & 23.4 & 39.5 & 8.72 & 2.24 \\
\hline IK22 & $32.615485^{\circ}$ & $38.00421^{\circ}$ & MS & 38 & 12,222 & 0.80 & 4.23 & 1.41 & 0.035 & 5.13 & 23.7 & 39.5 & 8.64 & 4.38 \\
\hline IK23 & $32.616727^{\circ}$ & $37.98518^{\circ}$ & MS & 42 & 10,977 & 0.79 & 4.26 & 1.80 & 0.047 & 4.75 & 22.6 & 39.6 & 8.53 & 3.31 \\
\hline IK24 & $32.617692^{\circ}$ & $37.97414^{\circ}$ & MS & 36 & 9422 & 0.85 & 4.40 & 1.19 & 0.009 & 5.09 & 23.5 & 39.5 & 8.56 & 3.82 \\
\hline IK25 & $32.620398^{\circ}$ & $38.06897^{\circ}$ & Mud & 41 & 15,600 & 0.84 & 4.53 & 1.66 & 0.030 & 4.45 & 23.8 & 40 & 8.66 & 11.75 \\
\hline IK26 & $32.619169^{\circ}$ & $38.07494^{\circ}$ & Mud & 59 & 15,288 & 0.88 & 5.21 & 1.59 & 0.019 & 4.62 & 23.6 & 40 & 8.79 & 17.88 \\
\hline IK27 & $32.618607^{\circ}$ & $38.07600^{\circ}$ & Mud & 56 & 20,266 & 0.79 & 4.62 & 1.93 & 0.030 & 4.21 & 22.9 & 39.5 & 8.81 & 12.51 \\
\hline IK28 & $32.617939^{\circ}$ & $38.07389^{\circ}$ & Mud & 50 & 14,911 & 0.89 & 5.03 & 1.47 & 0.022 & 4.61 & 23.1 & 39.3 & 8.79 & 19.12 \\
\hline IK29 & $32.617869^{\circ}$ & $38.06651^{\circ}$ & Mud & 55 & 19,777 & 0.82 & 4.76 & 1.93 & 0.014 & 4.18 & 22.7 & 39.1 & 8.72 & 12.48 \\
\hline IK30 & $32.617809^{\circ}$ & $38.06019^{\circ}$ & Mud & 46 & 15,511 & 0.87 & 4.80 & 1.60 & 0.025 & 4.64 & 22.8 & 39.2 & 8.95 & 17.15 \\
\hline IK31 & $32.617834^{\circ}$ & $38.05597^{\circ}$ & Mud & 63 & 19,400 & 0.84 & 5.02 & 1.50 & 0.010 & 4.58 & 23.6 & 40.1 & 8.87 & 13.85 \\
\hline IK32 & $32.617236^{\circ}$ & $38.04860^{\circ}$ & Mud & 55 & 14,533 & 0.89 & 5.18 & 1.64 & 0.014 & 4.33 & 23.7 & 40.2 & 8.87 & 9.23 \\
\hline IK33 & $32.616991^{\circ}$ & $38.03384^{\circ}$ & Mud & 57 & 18,022 & 0.83 & 4.86 & 1.70 & 0.017 & 4.23 & 24.1 & 40.5 & 8.53 & 17.75 \\
\hline IK34 & $32.616639^{\circ}$ & $38.02401^{\circ}$ & Mud & 49 & 15,688 & 0.83 & 4.66 & 1.55 & 0.016 & 4.69 & 24.4 & 39.4 & 8.85 & 13.13 \\
\hline
\end{tabular}


Table 2. Spatial-temporal variations of main physico-chemical parameters across three seasons (A: autumn; W: winter; S: summer), the parameters for spring are reported in Table 1. Hm: heavy metal contents.

\begin{tabular}{|c|c|c|c|c|c|c|c|c|c|c|c|c|c|}
\hline \multirow{2}{*}{\multicolumn{2}{|c|}{ Characteristics }} & \multicolumn{12}{|c|}{ Stations } \\
\hline & & IK1 & IK2 & IK3 & IK4 & IK5 & IK6 & IK7 & IK8 & IK9 & IK10 & IK11 & IK12 \\
\hline \multirow{3}{*}{$\underbrace{0}_{=}$} & A & 27.2 & 26.6 & 26.7 & 26.4 & 26.8 & 26.3 & 26.5 & 26.7 & 26.9 & 26.6 & 26.4 & 26.2 \\
\hline & W & 13.0 & 13.3 & 13.5 & 13.9 & 13.2 & 13.1 & 13.5 & 12.3 & 13.0 & 13.3 & 13.5 & 13.1 \\
\hline & S & 29.7 & 30.3 & 29.6 & 30.0 & 30.0 & 31.0 & 30.3 & 30.2 & 29.7 & 30.0 & 30.0 & 29.9 \\
\hline \multirow{3}{*}{$\bar{n}$} & A & 41.3 & 40.7 & 40.4 & 41.0 & 40.5 & 40.9 & 39.7 & 41.8 & 41.4 & 41.1 & 41.0 & 40.5 \\
\hline & $\mathrm{W}$ & 38.9 & 38.2 & 38.3 & 39.0 & 38.3 & 38.8 & 39.2 & 39.1 & 38.9 & 38.3 & 38.5 & 38.3 \\
\hline & S & 39.5 & 39.5 & 40.1 & 39.9 & 39.9 & 40.0 & 39.9 & 40.3 & 40.7 & 39.9 & 39.7 & 39.3 \\
\hline \multirow{3}{*}{ 要 } & A & 8.74 & 8.78 & 8.85 & 8.10 & 8.94 & 8.94 & 8.93 & 8.92 & 8.99 & 8.91 & 8.12 & 8.00 \\
\hline & W & 8.05 & 7.84 & 8.20 & 7.81 & 8.30 & 7.50 & 8.00 & 7.91 & 7.92 & 8.10 & 8.23 & 8.40 \\
\hline & S & 8.34 & 8.47 & 8.75 & 8.46 & 8.52 & 8.85 & 8.20 & 8.78 & 8.36 & 8.55 & 8.71 & 8.66 \\
\hline \multirow{3}{*}{$\frac{\mathfrak{d}}{\sum_{0}^{0}}$} & A & 1.70 & 2.21 & 2.01 & 1.86 & 2.61 & 4.02 & 2.42 & 2.19 & 2.90 & 1.69 & 2.48 & 5.28 \\
\hline & W & 1.62 & 1.98 & 1.79 & 1.93 & 2.11 & 3.68 & 2.68 & 1.98 & 2.64 & 1.82 & 2.18 & 4.88 \\
\hline & S & 1.89 & 2.56 & 1.58 & 2.01 & 3.12 & 3.12 & 2.71 & 2.42 & 2.86 & 2.1 & 2.10 & 4.12 \\
\hline \multirow{5}{*}{ 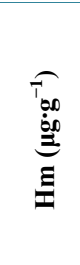 } & $\mathrm{Zn}$ & 546.4 & 465.25 & 638.75 & 529.75 & 543.25 & 655.5 & 181.49 & 557 & 266.71 & 565.00 & 422.38 & 388.42 \\
\hline & $\mathrm{Pb}$ & 18.76 & 31.53 & 39.65 & 34.23 & 33.76 & 37.75 & 31.16 & 36.52 & 27.12 & 44.48 & 32.82 & 36.98 \\
\hline & $\mathrm{Fe}$ & 129.87 & 138.6 & 154.2 & 558.9 & 561.2 & 770.1 & 515.4 & 438.7 & 269.1 & 339.9 & 386.24 & 288.60 \\
\hline & $\mathrm{Cd}$ & 0.186 & .912 & 0.737 & 0.527 & 0.496 & 0.629 & 0.539 & 0.417 & 0.480 & 0.464 & 0.682 & 0.583 \\
\hline & $\mathrm{P}$ & 478.35 & 528.31 & 311.42 & 548.12 & 462.32 & 386.23 & 386.12 & 498.61 & 792.01 & 687.42 & 724.32 & 698.43 \\
\hline
\end{tabular}

\section{Results}

\subsection{Abiotic Parameters}

The granulometric analyses reveal that there are three main types of sediment: medium sand, fine sand, and mud (Table 1). Moreover, all sampled stations are colonized by Zostera noltei eelgrass beds.

For the physical and chemical parameters, only one measurement was carried out for the whole set of 34 sampled stations in April 2014 (Table 1). The temperatures range from 22.6 to $24.4^{\circ} \mathrm{C}$ (mean $=23.3 \pm \mathrm{SD} 0.46$ ) for temperature, the salinity from 39.1 to 40.5 (mean $=39.6 \pm$ SD 0.32), the $\mathrm{pH}$ from 8.05 to 8.95 (mean $=8.7 \pm$ SD 0.18 ) and organic matter content from $1.32 \%$ to $19.12 \%$ (mean $=6.16 \pm$ SD 5.78). Temperature, salinity and $\mathrm{pH}$ appear homogeneous between the 34 stations. The organic matter shows significant differences between the three sediment types (ANOVA, $\mathrm{F}_{2,31}=134.9 ; p<0.01$ ); the percentage of organic matter is higher in the mud than in the fine or medium sands. No difference is observed between the medium and fine sand (Tukey test).

ANOVA shows that temperature, salinity and $\mathrm{pH}$ differ significantly between seasons, with temperatures varying between $12.3^{\circ} \mathrm{C}$ in winter (IK8) and $31^{\circ} \mathrm{C}$ in summer (station 6), salinity between 38.2 in winter (IK2) and 41.8 in autumn (IK5), pH between 7.84 (IK2) in winter and 8.99 in autumn (IK9) and organic matter between 1.32 (IK4) and 5.28\% (IK12). The Tukey test reveals that the temperature and salinity differ significantly between the four seasons, whereas the $\mathrm{pH}$ differs only in winter.

As regards the heavy metals, Zn varies between 181.49 and $638.75 \mu \mathrm{g} \cdot \mathrm{g}^{-1}$, Pb between 18.76 and $44.42 \mu \mathrm{g} \cdot \mathrm{g}^{-1}$, Fe between 129.87 and $770.10 \mu \mathrm{g} \cdot \mathrm{g}^{-1}$, while Cd levels do not exceed $1 \mu \mathrm{g} \cdot \mathrm{g}^{-1}$. Phosphate contents fluctuate between 311.42 (IK3) and $792.01 \mu \mathrm{g} \cdot \mathrm{g}^{-1}$ (IK11) (Table 2).

\subsection{Macrofaunal Characteristics}

The taxonomic identification of the collected invertebrates produced a list of 159 taxa belonging to six zoological groups. Crustaceans are dominant (32\% of the total number of taxa), followed by molluscs (29\%) and anne- 
lid polychaetes (27\%). The three other phyla identified (echinoderms, cnidarians and tunicates) account for only $12 \%$ of the total number of taxa. The faunistic parameters show a wide range of variability, from 9244 to 36,844 ind $\cdot \mathrm{m}^{-2}$ for abundance (with a mean abundance of $14,346 \pm$ S.D. 3540 ind $\cdot \mathrm{m}^{-2}$ ), 22 to 63 taxa for specific richness, 0.68 to 0.90 for evenness and 3.53 to 5.18 bits./ind. for the Shannon index (Table 1). Trophic structure analysis shows that the majority of stations are strongly represented by carnivores (41\%), followed by nonselective deposit feeders NSDF (16\%), herbivores (16\%), selective deposit feeders SDF (15\%) and suspension feeders SF (12\%).

For the 12 stations monitored seasonally over one year (Figure 2), the specific richness (a) and the abundance (b) display temporal fluctuations. The number of taxa varies significantly between 16 in winter (IK11 and IK12) and 40 in summer and autumn (IK5 and IK8) (ANOVA, $\mathrm{F}_{3,44}=14.98 ; p<0.001$ ). The number of individuals varies significantly between 3111 ind $\cdot \mathrm{m}^{-2}$ in winter (IK12) and $21,022 \mathrm{ind} \cdot \mathrm{m}^{-2}$ in spring (IK4) (ANOVA, $\mathrm{F}_{3,44}=$ 48.6; $p<0.001$ ). The Tukey test reveals the absence of any difference in abundance between summer and the autumn; whereas for the taxonomic richness, the winter period differs from the three other seasons with a depletion of species. The evenness (J') and Shannon-Wiener diversity ( $\left.\mathrm{H}^{\prime}\right)$ also show fluctuations, with the highest values being observed in summer and autumn. The Shannon-Weaver diversity shows a diversified population across the seasons and is highly diversified during the summer (except for IK1) (Figure 2). Pielou's evenness $(\mathrm{J}$ ') reflects the absence of species dominance in the population between the four seasons.

AMBI, BO2A and BENTIX indices are consistent with the results classifying all stations as having good ecological status (Table 1). In fact, the majority of stations were strongly dominated by sensitive (EGI) and indifferent species (EGII). ANOVA did not indicate any significant differences for these biotic indices between the all stations $(p<0.05)$.
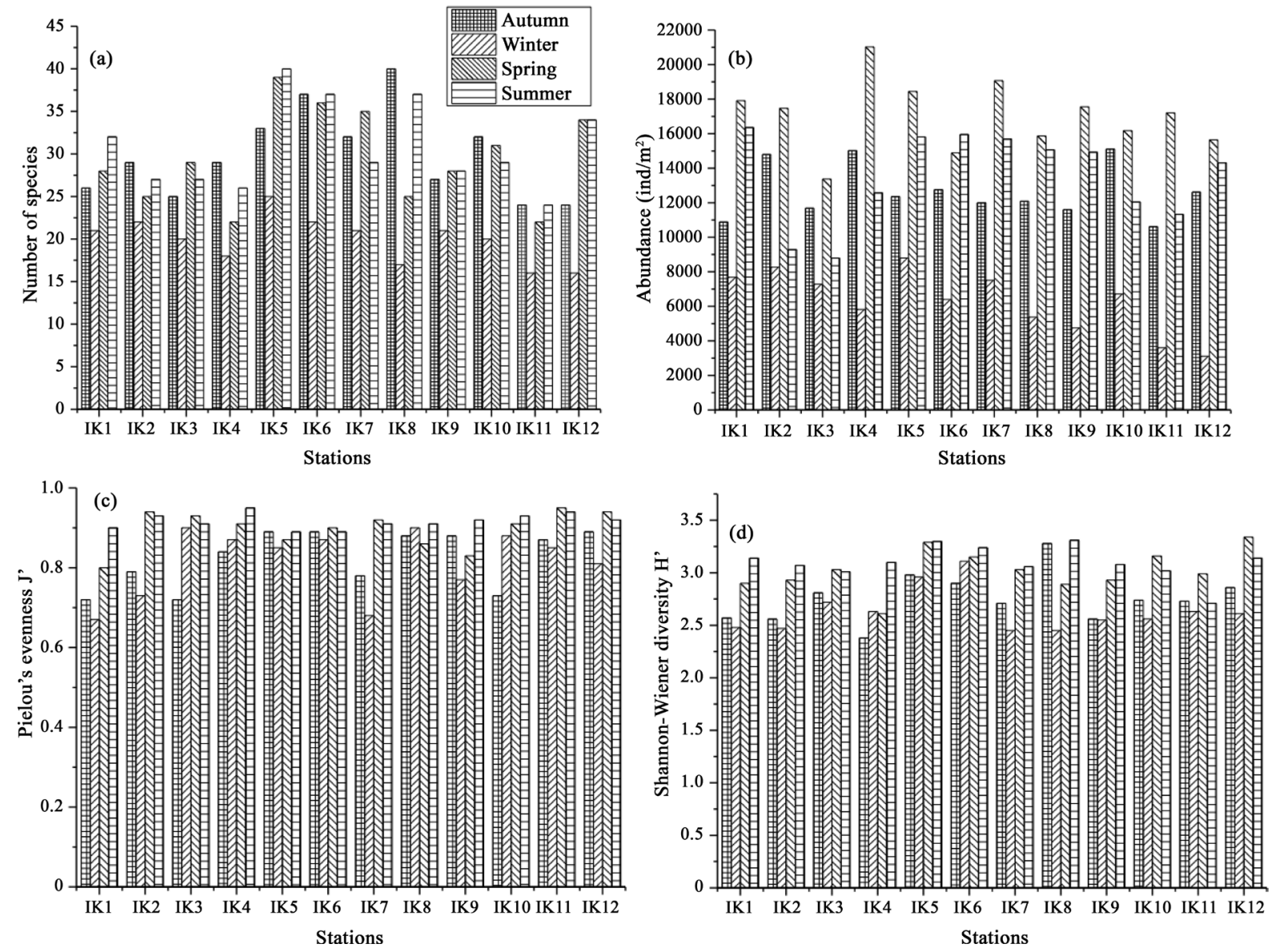

Figure 2. Spatial and seasonal variability of the principal benthic macrofauna parameters in the Kneiss Islands: specific richness (a), abundance (b), Pielou's evenness (c) and Shannon-Wiener index (d). 


\subsection{Multivariate Analysis}

The dendrogram and MDS ordination (Figure 3) allow us to separate the 34 stations into three main groups: the first group (GI) corresponds to the twelve stations sampled around Bessila Islet (IK1 to IK12), mainly made up of fine sand, except for IK2 and IK11 which are composed of medium sand; the second group (GII) corresponding to the twelve stations sampled on Laboua Islet (IK13 to IK24), composed solely of medium sand; and the third and last group (GIII) comprising the other 10 stations (IK25 to IK34) located near the port of embarkation and along a tidal channel characterized by mud sediments.

SIMPER analysis (Table 3) show that GIII shows the most significant similarity between group members (56.90\% contribution to total similarity), this group being characterized by numerous representative species especially Perinereis cultifera (Grube, 1840), Gammarus insensibilis (Stock, 1966), Cerastoderma glaucum (Bruguière, 1789) and Arenicola marina (Linnaeus, 1758). SIMPER analysis also indicates that Melinna palmate (Grube, 1870), Loripes lucinalis (Lamarck, 1818), Euclymene oerstedii (Claparède, 1863), and Cirratulus cirratus (O.F. Müller, 1776) contribute significantly to similarities within groups I and II.

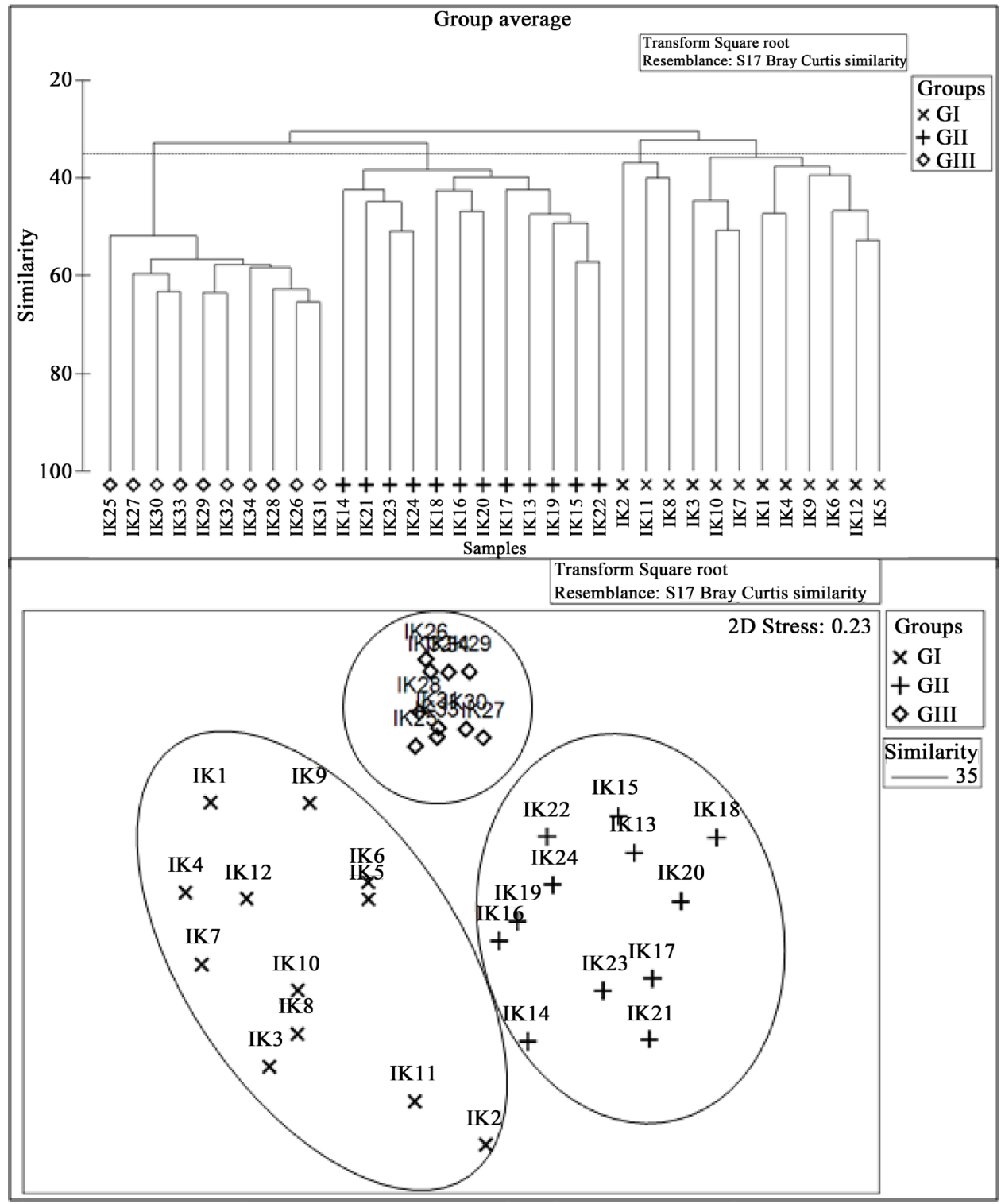

Figure 3. Dendrogram and MDS ordination of Bray-Curtis similarities from abundance data (square root transformation) for 34 sampling stations in the intertidal zone of the Kneiss Islands. 
Table 3. MDS formed groups, with indication of similarities within each group (\%) and the most representative species (\%) contributing to the similarity within the group, determined by SIMPER analysis.

\begin{tabular}{|c|c|c|c|}
\hline Group & $\mathbf{I}$ & II & III \\
\hline Group mean similarity (\%) & 36.11 & 40.85 & 56.90 \\
\hline \multirow{10}{*}{$\begin{array}{l}\text { Main species (the \% } \\
\text { contribution to the similarity } \\
\text { within each group is given for } \\
\text { each species) }\end{array}$} & Melinna palmate: 47.70 & Melinna palmata: 52.81 & Nereis cultifera: 54.22 \\
\hline & Euclymene lumbricoides: 44.96 & Cymadusa filosa: 50.42 & Gammarus insensibilis: 51.02 \\
\hline & Bittium reticulatum: 42.15 & Tricolia speciosa: 47.46 & Cerastoderma glaucum: 47.38 \\
\hline & Arenicola marina: 39.19 & Lumbrineris tetraura: 44.30 & Arenicola marina: 43.40 \\
\hline & Euclymene oerstedi: 35.25 & Loripes lucinalis: 40.85 & Pseudocuma longicornis: 38.98 \\
\hline & Loripes lucinalis: 31.05 & Euclymene oerstedi: 37.08 & Cirratulus cirratus: 29.51 \\
\hline & Ruditapes decussates: 26.05 & Potamides conicus: 32.99 & Bittium reticulatum: 24.38 \\
\hline & Cirratulus cirratus: 19.93 & Cirratulus cirratus: 27.25 & Cerithium scabridum: 19.14 \\
\hline & Cerastoderma glaucum: 13.6 & Scrobicularia plana: 20.56 & Scrobicularia plana: 13.72 \\
\hline & Cerithium scabridum: 7.17 & Cerithium scabridum: 10.42 & Potamides conicus: 7.54 \\
\hline
\end{tabular}

\section{Discussion}

This study reports the spatial and temporal variability of benthic macrofauna communities over the whole intertidal zone of the Kneiss Islands in the Gulf of Gabès, i.e. an inventory of species associated with Zostera eelgrass, distributed in the intertidal ecosystem, along with the spatial distribution of macrobenthic fauna assemblages, as well as the seasonal variations according to the main environmental changes and anthropogenic pressures, especially traditional human activities.

\subsection{Characteristics of the Different Faunal Assemblages}

In the present study, three distinct macrofaunal assemblages can be recognized in the apparently homogeneous Zostera noltei meadow. The assemblages are characterized by spatial and temporal changes in the population, and their distribution pattern seems to be entirely governed by the physico-chemical and edaphic characteristics of the environment. The faunal assemblages of groups II (12 stations) and III (10 stations) make up the two most representative aspects of the $Z$. noltei macrobenthic communities. They comprise $65 \%$ of stations, being densely vegetated compared to the poorly vegetated stations of group I. Granulometric analyses show that the sediments on the foreshore of the Kneiss Islands are generally fine grained. Seagrass cover and different sediment characteristics indicate that these two factors play an important role in the establishment of different macrozoobenthic assemblages within a Zostera noltei habitat, thus confirming the results found by [4] for the benthic assemblage patterns in Arcachon Bay, France. Furthermore, many ecological studies on benthic fauna note the importance of sediment grain-size in controlling the distribution of the communities. Indeed, certain species colonize very fine sediments in which they build tubes or other protecting biogenic constructions of mud, such as the tubicolous polychaete Melinna palmata Grube, 1870. Other organisms prefer sand or coarse sediment with high porosities [49]. Thus, sedimentary texture is a major factor affecting the distribution of benthic communities, and represents a paramount parameter that should not be ignored in the study of benthic fauna [50]-[53].

\subsection{Comparison with Other Zostera noltei Beds}

In this study, we identify 159 taxa, associated with intertidal Zostera noltei seagrass beds, which are unequally distributed among the sampling stations. The benthic community in the Kneiss Islands seems to be characterized by a structure and organization closely similar to ecosystems in other parts of the Mediterranean, dominated mainly by crustaceans, molluscs, polychaetes, cnidarians and echinoderms. This pattern has also been observed in other Mediterranean coastal sites, such as in the Kerkennah Islands [54], the Bay of Tunis, Ghar El-Melh Lagoon, the Tunis lagoon [55], the Venice Lagoon and Valle di Gorino (Adriatic Sea) [56] [57]. The most abun- 
dant species are Gammarus insensibilis (Stock, 1966), Scrobicularia plana (Linnaeus, 1758), Cerithium scabridum (Philippi, 1848), Potamides conicus (Blainville, 1829), Loripes lucinalis (Lamarck, 1818), Cirratulus cirratus (O.F. Müller, 1776), Perinereis cultifera (Grube, 1840) and Euclymene aestuarii (Claparède, 1863). There are scant studies on macrozoobenthic assemblages from seagrass-dominated areas in the intertidal zone, particularly in the Mediterranean region [4] [58] [59]. However, it is well known that seagrasses increase habitat complexity and provide living space and shelter for a diverse animal community [60]-[62]. Seagrass bed communities are usually characterized by a larger number of species and higher abundances than adjacent unvegetated sediments [63] [64]. The effect on these meadows is both structural, since it increases the complexity of the habitat, allowing different species to occupy various ecological niches within a given area, and trophic because it supports epiphytes, a resource for many grazers [65]. A higher abundance of macrofauna has often been reported in vegetated habitats [65] [66] and different explanatory mechanisms can be proposed; 1) decreased predation efficiency due to high habitat complexity [67]; 2) habitat preference of dense seagrass by prey as an escape mechanism from predation [5]; 3) stabilization of sediments leading to accumulation of organic matter, allowing increased settlement and growth of infauna [68] and 4) high content of organic matter, which attracts a certain type of infauna such as deposit-feeding polychaetes [62].

The dominant macrozoobenthic assemblages within the intertidal area colonized by the Zostera noltei seagrass beds of the Kneiss Islands (Table 3) are made up of species that are dominant in the Venice lagoon [57] and in Atlantic lagoons such as Arcachon Bay [4] [69]. Indeed, a large number of species and high abundances are observed in these study areas, associated with the probable positive effect of seagrass which is commonly related to the structural complexity of the canopy. This favors the successful recruitment and colonization of animals, while the interlacing rhizome layer and roots increase sediment stability [70].

\subsection{Seasonal Variability of Macrozoobenthic Communities}

During the study period, the macrozoobenthic composition was subject to predictable seasonal changes: the main community structure parameters fluctuated according to the typical seasonal cycle of coastal temperate waters [71]. The benthic population density and species richness shows seasonal variation in such a way that, at all stations, the maximum is recorded in spring and summer and the minimum during winter. The seasonal variations in mean abundance, diversity and community structure of the macrofauna benthic are mainly caused by recruitment in spring and summer [20]. Recruitment is reflected by a general increase in abundance and number of species during spring and summer and a decline during winter. Recruitment is known to be highly variable in space and time and is mainly influenced by numerous factors during the seasonal cycle such as food availability, water temperature, predation and the hydrodynamic regime [20] [72]-[74]. Thus, larval availability, larval settlement and the consequent post-recruitment processes such as growth and mortality will have a strong effect on the seasonal variability of the benthic communities [73] [75]. The seasonal variability of intertidal macrofauna benthic communities in the Kneiss Islands could be due to the impact of clam harvesting, which is intensively carried out during the winter, leading to a significant decrease in the taxonomic richness and abundance of the surrounding benthic macrofauna [27].

\subsection{Ecological Status of the Kneiss Islands}

Taken together, the calculated values of the various biotic indices show a certain degree of intercorrelation among themselves. Indeed, the majority of these indices classify all stations colonized by intertidal eelgrass meadows as having a good ecological status, with some having a high quality status (Table 1). An analysis of the ecological groups shows that the area is mostly represented by sensitive and indifferent species (EGI and EGII), while there is a lack of first-order opportunistic species (EGV) indicative of polluted environments. An ecological disturbance indicator is useful if it can be easily calculated, while remaining sensitive, anticipatory and integrative across key environmental gradients [76]. However, although a single index may provide a good overview of the gradient status of a given benthic environment, it is difficult to choose a particular index that will definitively establish the true status of a specific site [77]. For example, the AMBI index sometimes appears to be more appropriate for Atlantic ecosystems and estuarine areas with low biodiversity, few species and high densities, whereas the BENTIX index seems better suited to determining EcoQ in Mediterranean coastal ecosystems with high biodiversity [78]. 


\section{Conclusions}

Long-term studies are essential for understanding the natural variability of species composition, dominance structure and the functional diversity of benthic communities in relation to natural environmental drivers, all of which are affected by climate change [79]. This study focuses on the spatial and temporal variability of the taxonomic diversity and structure of the benthic macrofauna in the intertidal zone of the Kneiss Islands, which represents an important area in the Mediterranean as regards tidal range and avian biodiversity. The present study contributes an inventory of 159 macrobenthic species dominated by crustaceans and molluscs, which appears similar in terms of richness to the taxonomic list of other Mediterranean ecosystems. Moreover, we find that sediment type and organic matter content are the fundamental factors accounting for the distribution of assemblages of macrofauna on the tidal flats of the Kneiss Islands.

Finally, it would be of great interest to carry out the same type of study on the subtidal zones of the Kneiss Islands, characterized by the presence of submerged tidal channels. This particular Mediterranean ecosystem is subject to a range of anthropogenic pressures, which lead to a decrease in sediment grain-size from downstream to upstream under the action of tidal currents [80]. It is not clear whether these currents could have some incidence on the distribution of subtidal macrobenthic assemblages.

\section{Acknowledgements}

The authors thank M. Carpenter for the English revision, as well as the fishers of the Kneiss Islands for their help during the sampling and the Laboratory team of GeoResources Materials, Environment and Global Changes (FSS) for their assistance during sediment analysis.

\section{References}

[1] Afli, A., Ayari, R. and Brahim, M. (2008) Trophic Organization of the Macro-Zoobenthic Assemblages within Coastal Areas Subjected to Anthropogenic Activities. Journal of the Marine Biological Association of the United Kingdom, 88, 663-674. http://dx.doi.org/10.1017/S0025315408001318

[2] Hadjibiros, K. (2013) Ecology and Applied Environmental Science. CRC Press, Taylor and Francis Group, Boca Raton, $234 \mathrm{p}$.

[3] Morrisey, D.J., Skilleter, G.A., Ellis, J.I., Burns, B.R., Kemp, C.E. and Burt, K. (2003) Differences in Benthic Fauna and Sediment among Mangrove (Avicennia marina var. australasica) Stands of Different Ages in New Zealand. Estuarine, Coastal and Shelf Science, 56, 581-592. http://dx.doi.org/10.1016/S0272-7714(02)00208-1

[4] Blanchet, H., de Montaudouin, X., Lucas, A. and Chardy, P. (2004) Heterogeneity of Macrozoobenthic Assemblages within a Zostera noltii Seagrass Bed: Diversity, Abundance, Biomass and Structuring Factors. Estuarine, Coastal and Shelf Science, 61, 111-123. http://dx.doi.org/10.1016/j.ecss.2004.04.008

[5] Boström, C., O’Brien, K., Roos, C. and Ekebom, J. (2006) Environmental Variables Explaining Structural and Functional Diversity of Seagrass Macrofauna in an Archipelago Landscape. Journal of Experimental Marine Biology and Ecology, 335, 52-73. http://dx.doi.org/10.1016/j.jembe.2006.02.015

[6] Kennesh, M.J. (2002) Environmental Threats and Environmental Future of Estuaries. Environmental Conservation, 29, 78-107. http://dx.doi.org/10.1017/s0376892902000061

[7] Kemp, W.M., Boynton, W.R., Adolf, J.E., Boesch, D.F., Bolcourt, W.C., Brush, G., Cornwell, J.C., et al. (2005) Eutrophication of Chesapeake Bay: Historical Trends and Ecological Interactions. Marine Ecology Progress Series, 303, 1-29. http://dx.doi.org/10.3354/meps303001

[8] Lotze, H.K., Lenihan, H.S., Bourque, B.J., Bradbury, R.H., Cooke, R.G., Kay, M.C., Kidwell, S.M., et al. (2006) Depletion, Degradation, and Recovery Potential of Estuaries and Coastal Seas. Science, 312, 1806-1809.

http://dx.doi.org/10.1126/science.1128035

[9] Airoldi, L. and Beck, M.W. (2007) Loss, Status and Trends for Coastal Marine Habitats of Europe. Oceanography and Marine Biology: An Annual Review, 45, 345-405.

[10] Andersen, J.H., Schuter, L. and Ærtebjerg, G. (2006) Coastal Eutrophication: Recent Developments in Definitions and Implications for Monitoring Strategies. Journal of Plankton Research, 28, 621-628. http://dx.doi.org/10.1093/plankt/fbl001

[11] Borja, A. (2006) The New European Marine Strategy Directive: Difficulties, Opportunities and Challenges. Marine Pollution Bulletin, 52, 239-242. http://dx.doi.org/10.1016/j.marpolbul.2005.12.007

[12] Borja, A. and Dauer, D.M. (2008) Assessing the Environmental Quality Status in Estuarine and Coastal Systems: 
Comparing Methodologies and Indices. Ecological Indicators, 8, 331-337. http://dx.doi.org/10.1016/j.ecolind.2007.05.004

[13] Dauer, D.M., Ranasinghe, J.A. and Weisberg, S.B. (2000) Relationships between Benthic Community Condition, Water Quality, Sediment Quality, Nutrient Loads, and Land Use Patterns in Chesapeake Bay. Estuaries, 23, 80-96. http://dx.doi.org/10.2307/1353227

[14] Sundblad, G., Bergström, U. and Sandström, A. (2011) Ecological Coherence of Marine Protected Area Networks: A Spatial Assessment Using Species Distribution Models. Journal of Applied Ecology, 48, 112-120. http://dx.doi.org/10.1111/j.1365-2664.2010.01892.x

[15] Beck, M.W., Heck Jr., K.L., Able, K.W., Childers, D.L., Eggleston, D.B., Gillanders, B.M., Halpern, B., et al. (2001) The Identification, Conservation, and Management of Estuarine and Marine Nurseries for Fish and Invertebrates. BioScience, 51, 633-641. http://dx.doi.org/10.1641/0006-3568(2001)051[0633:TICAMO]2.0.CO;2

[16] Worm, B., Barbier, E.B., Beaumont, N., Duffy, J.E., Folke, C., Halpern, B.S., Jackson, J.B.C., et al. (2006) Impacts of Biodiversity Loss on Ocean Ecosystem Services. Science, 314, 787-790. http://dx.doi.org/10.1126/science.1132294

[17] Mosbahi, N., Boudaya, L., Dauvin, J.C. and Neifar, N. (2015) Spatial Distribution and Abundance of Intertidal Benthic Macrofauna in the Kneiss Islands (Gulf of Gabès, Tunisia). Cahiers de Biologie Marine, 56, 319-328.

[18] Pearson, T.H. and Rosenberg, R. (1978) Macrobenthic Succession in Relation to Organic Enrichment and Pollution of the Marine Environment. Oceanography and Marine Biology: An Annual Review, 16, 229-311.

[19] Dauvin, J.C. (1993) Le benthos: Témoin des variations de l'environnement. Océanis, 19, 25-53.

[20] Reiss, H. and Kroncke, I. (2005) Seasonal Variability of Benthic Indices: An Approach to Test the Applicability of Different Indices for Ecosystem Quality Assessment. Marine Pollution Bulletin, 50, 1490-1499. http://dx.doi.org/10.1016/j.marpolbul.2005.06.017

[21] Blanchet, H., Lavesque, N., Ruellet, T., Dauvin, J.C., Sauriau, P.G., Desroy, N., Desclaux, C., Leconte, M., Bachelet, G., Janson, A.L., Bessineton, C., Duhamel, S., Jourde, J., Mayot, S., Simon, S. and De Montaudouin, X. (2008) Use of Biotic Indices in Semi-Enclosed Coastal Ecosystems and Transitional Waters Habitats-Implications for the Implementation of the European Water Framework Directive. Ecological Indicators, 8, 360-372. http://dx.doi.org/10.1016/j.ecolind.2007.04.003

[22] Hamza, F., Hammouda, A. and Selmi, S. (2015) Species Richness Patterns of Waterbirds Wintering in the Gulf of Gabes in Relation to Habitat and Anthropogenic Features. Estuarine, Coastal and Shelf Science, 165, 254-260. http://dx.doi.org/10.1016/j.ecss.2015.05.025

[23] Whitfield, A.K. (1998) Biology and Ecology of Fishes in Southern African Estuaries. Ichthyological Monographs of the J.L.B. Smith Institute of Ichthyology, 2, 223 p. http://dx.doi.10.1023/A:1008968200973

[24] Le Mao, P., Pasco, P.Y. and Provost, S. (2006) Consommation de la macrofaune invertébrée benthique par les oiseaux d'eau en baie du Mont-Saint-Michel. Alauda, 74, 23-36. http://archimer.ifremer.fr/doc/00000/2600/

[25] Hattour, A. (1991) Le chalutage dans les eaux tunisiennes, réalités et considérations législatives particulièrement dans les golfes de Tunis et de Gabès. Notes de l'Institut National des Sciences et Technologies d'Océanographie et de Pêche de Salammbô, 1, 1-25.

[26] M’Rabet, R. (1995) Les engins de pêche et les ressources halieutiques. Notes de l'Institut National Scientifique et Technique d'Océanographie et de Pêche de Salammbô, 6, 1-29.

[27] Mosbahi, N., Pezy, J.P., Dauvin, J.C. and Neifar, L. (Submitted) Effects of Clam Harvesting on Macrofauna Diversity in Sand and Mudflat Zones of the Kneiss Islands (Gulf of Gabès, Tunisia). Helgoland Marine Research.

[28] Mosbahi, N., Pezy, J.P., Dauvin, J.C. and Neifar, L. (2016) Short-Term Impact of Bait Digging on Intertidal Macrofauna of Tidal Mudflats around the Kneiss Islands (Gulf of Gabès, Tunisia). Aquatic Living Resources, 28, 111-118. http://dx.doi.10.1051/alr/2016002

[29] Béjaoui, B., Rais, S. and Koutitonsky, V. (2004) Modélisation de la dispersion du phosphogypse dans le golfe de Gabès. Bulletin de l'Institut National des Sciences et Technologies de la Mer de Salammbô, Tunisia, 31, 113-119.

[30] Galil, B.S. (2007) Loss or Gain? Invasive Aliens and Biodiversity in the Mediterranean Sea. Marine Pollution Bulletin, 55, 314-322. http://dx.doi.org/10.1016/j.marpolbul.2006.11.008

[31] Adloff, F., Somot, S., Sevault, F., Jordà, G., et al. (2015) Mediterranean Sea Response to Climate Change in an Ensemble of Twenty First Century Scenarios. Climate Dynamics, 45, 2775-2802. http://dx.doi.org/10.1007/s00382-015-2507-3

[32] Sammari, C., Koutitonsky, V.G. and Moussa, M. (2006) Sea Level Variability and Tidal Resonance in the Gulf of Gabès, Tunisia. Continental Shelf Research, 26, 338-350. http://dx.doi.org/10.1016/j.csr.2005.11.006

[33] Abdennadher, A., Ramirez, F., Romdhane, M.S., Ruiz, L.J. and Sanpera, C. (2010) Biomonitoring of Coastal Areas in Tunisia: Stable Isotope and Trace Element Analysis in the Yellow-Legged Gull. Marine Pollution Bulletin, 60, 440- 
447. http://dx.doi.org/10.1016/j.marpolbul.2009.10.003

[34] Yoshida, M., Hamadi, K. and Ghrabi, A. (2002) Solid Waste Landfills and Soil/Sediment Contamination around Bizerte Lagoon: Possible Pollution Sources. RPP-SEPMCL Initial Report, 55-75.

[35] Shannon C.E. and Weaver W. (1963) The Mathematical Theory of Communication. University Illinois Press, Urbana, $117 \mathrm{p}$.

[36] Pielou, E.C. (1966) Shannon's Formula as a Measure of Specific Diversity: Its Use and Measure. American Naturalist, 100, 463-465. http://dx.doi.org/10.1086/282439

[37] Vincent, C., Heinrich, H., Edwards, A., Nygaard, K. and Haythornthwaite, J. (2002) Guidance on Typology, Classification and Reference Conditions for Transitional and Coastal Waters. Commission Européenne, CIS WG 2.4 (COAST), 119 p.

[38] Fauchald, K. and Jumars, P.A. (1979) The Diet of Worms: A Study of Polychaete Feeding Guilds. Oceanography and Marine Biology: Annual Review, 17, 173-284.

[39] Grall, J. and Glémarec, M. (1997) Using Biotic Indices to Estimate Macrobenthic Community Perturbations in the Bay of Brest. Estuarine and Coastal Shelf Science, 44, 43-53. http://dx.doi.org/10.1016/S0272-7714(97)80006-6

[40] Hily, C. and Bouteille, M. (1999) Modifications of the Specific Diversity and Feeding Guilds in an Intertidal Sediment Colonized by an Eelgrass Meadow (Zostera marina) (Brittany, France). Comptes Rendus de l'Académie des SciencesSeries III-Sciences de la Vie, 322, 1121-1131. http://dx.doi.org/10.1016/s0764-4469(99)00112-2

[41] Afli, A. and Glémarec, M. (2000) Fluctuation à long terme des peuplements macrobenthiques de la partie orientale du golfe du Morhiban (Bretagne, France). Cahiers de Biologie Marine, 41, 67-89.

[42] Pranovi, F., Curiel, D., Rismondo, A., Marzocchi, M. and Scattolin, M. (2000) Determination of Food Sources for Benthic Invertebrates in a Salt Marsh (Aiguillon Bay, France) by Carbon and Nitrogen Stable Isotopes: Importance of Locally Produced Sources. Scientia Marina, 64, 303-388.

[43] Borja, A., Franco, J. and Pérez, V. (2000) A Marine Biotic Index to Establish the Ecology Quality of Soft Bottom Benthos within European Estuarine Coastal Environments. Marine Pollution Bulletin, 40, 1100-1114. http://dx.doi.org/10.1016/S0025-326X(00)00061-8

[44] Simboura, N. and Zenetos, A. (2002) Benthic Indicators to Use in Ecological Quality Classification of Mediterranean Soft Bottom Marine Ecosystems, Including a Biotic Index. Mediterranean Marine Science, 3, 77-111. http://dx.doi.org/10.12681/mms.249

[45] Simboura, N., Panayotidis, P. and Papathanassiou, E. (2005) A Synthesis of the Biological Quality Elements for the Implementation of the European Water Framework Directive in the Mediterranean Ecoregion: The Case of Saronikos Gulf. Ecological Indicators, 5, 253-266. http://dx.doi.org/10.1016/j.ecolind.2005.03.006

[46] Dauvin, J.C., Ruellet, T., Desroy, N. and Janson, A.L. (2007) The Ecological Quality Status of the Bay of Seine and the Seine Estuary: Use of Biotic Indices. Marine Pollution Bulletin, 55, 241-257. http://dx.doi.org/10.1016/j.marpolbul.2006.04.010

[47] Dauvin, J.C. and Ruellet, T. (2009) The Estuarine Quality Paradox: Is It Possible to Define an Ecological Quality Status for Specific Modified and Naturally Stressed Estuarine Ecosystems? Marine Pollution Bulletin, 59, 38-47. http://dx.doi.org/10.1016/j.marpolbul.2008.11.008

[48] Clarke, K.R. and Gorley, R.N. (2006) Primer v6: User Manual/Tutorial. Primer-E Ltd., Plymouth.

[49] Desroy, N. and Retière, C. (2001) Long-Term Changes in Muddy Fine Sand Community of the Rance Basin: Role of Recruitment. Journal of the Marine Biological Association of the United Kingdom, 81, 553-564.

[50] Glémarec, M. and Hily, C. (1981) Perturbations apportées à la macrofaune benthique de la baie de Concarneau par les effluents urbains et portuaires. Acta Oecologica Applicata, 2, 139-150.

[51] Hily, C. (1984) Variabilité de la macrofaune benthique dans les milieux hyper-trophiques de la rade de Brest, volume 1. $\mathrm{PhD}$ Thesis, University of La Bretagne Occidentale, France.

[52] Le Bris, H. (1988) Fonctionnement des écosystèmes benthiques au contact des estuaires: La rade de Lorient et la baie de Vilaine. PhD Thesis, University of La Bretagne Occidentale, France.

[53] Dauvin, J.C., Thiébaut, E., Gomez Gesteira, J.L., Ghertsos, K., Gentil, F., Ropert, M. and Sylvand, B. (2004) Spatial Structure of a Subtidal Macrobenthic Community in the Bay of Veys (Western Bay of Seine, English Channel). Journal of Experimental Marine Biology and Ecology, 307, 217-235. http://dx.doi.org/10.1016/j.jembe.2004.02.005

[54] Aloui-Bejaoui, N. and Afli, A. (2011) Functional Diversity of the Macro-Invertebrate Community in the Port Area of Kerkennah Islands (Tunisia). Mediterranean Marine Science, 13, 93-102.

[55] Afli, A., Chakroun, R., Ayari, R. and Aissa, P. (2009) Seasonal and Spatial Variability of the Community and Trophic Structure of the Benthic Macrofauna within Tunisian Lagoonal and Marine Coastal Areas (Southwestern Mediterranean). Journal of Coastal Research, 256, 1198-1209. http://dx.doi.org/10.2112/08-1078.1 
[56] Munari, C. and Mistri, M. (2008) The Performance of Benthic Indicators of Ecological Change in Adriatic Coastal Lagoons: Throwing the Baby with the Water? Marine Pollution Bulletin, 56, 95-105. http://dx.doi.org/10.1016/j.marpolbul.2007.09.037

[57] Tagliapietra, D., Pessa, G., Cornello, M., Zitelli, A. and Magni, P. (2016) Temporal Distribution of Intertidal Macrozoobenthic Assemblages in a Nanozostera noltii-Dominated Area (Lagoon of Venice). Marine Environmental Research, 114, 31-39. http://dx.doi.org/10.1016/j.marenvres.2015.11.009

[58] Bachelet, G., de Montaudouin, X., Auby, I. and Labourg, P.J. (2000) Seasonal Changes in Macrophyte and Macrozoobenthos Assemblages in Three Coastal Lagoons under Varying Degrees of Eutrophication. ICES Journal of Marine Science, 57, 1495-1506. http://dx.doi.org/10.1006/jmsc.2000.0902

[59] Bouma, T.J., Ortells, V. and Ysebaert, T. (2009) Comparing Biodiversity Effects among Ecosystem Engineers of Contrasting Strength: Macrofauna Diversity in Zostera noltii and Spartina anglica Vegetations. Helgoland Marine Research, 63, 3-18. http://dx.doi.org/10.1007/s10152-008-0133-8

[60] Hemminga, M.A. and Duarte, C.M. (2000) Seagrass Ecology. Cambridge University Press, Cambridge. http://dx.doi.org/10.1017/CBO9780511525551

[61] Duffy, J.E. (2006) Biodiversity and the Functioning of Seagrass Ecosystems. Marine Ecology Progress Series, 311, 233-250. http://dx.doi.org/10.3354/meps311233

[62] Fredriksen, S., De Backer, A., Bostrom, C. and Christie, H. (2010) Infauna from Zostera marina L. Meadows in Norway. Differences in Vegetated and Unvegetated Areas. Marine Biology Research, 6, 189-200. http://dx.doi.org/10.1080/17451000903042461

[63] Bowden, D.A., Rowden, A.A. and Martin, J.A. (2001) Effect of Patch Size and In-Patch Location on the Infaunal Macroinvertebrate Assemblages of Zostera marina Seagrass Beds. Journal of Experimental Marine Biology and Ecology, 259,133-154. http://dx.doi.org/10.1016/S0022-0981(01)00236-2

[64] Barnes, R.S.K. and Barnes, M.K.S. (2012) Shore Height and Differentials between Macrobenthic Assemblages in Vegetated and Unvegetated Areas of an Intertidal Sandflat. Estuarine, Coastal and Shelf Science, 116, 112-120. http://dx.doi.org/10.1016/j.ecss.2012.05.011

[65] Duffy, J.E., Richardson, J.P. and Canuel, E.A. (2003) Grazer Diversity Effects on Ecosystem Functioning in Seagrass Beds. Ecology Letters, 6, 637-645. http://dx.doi.org/10.1046/j.1461-0248.2003.00474.x

[66] Boström, C. and Bonsdorff, E. (1997) Community Structure and Spatial Variation of Benthic Invertebrates Associated with Zostera marina (L.) Beds in the Northern Baltic Sea. Journal of Sea Research, 37, 153-166. http://dx.doi.org/10.1016/S1385-1101(96)00007-X

[67] Orth, R.J., Heck, K.L.J. and van Montfrans, J. (1984) Faunal Communities in Seagrass Beds: A Review of the Influence of Plant Structure and Prey Characteristics on Predator-Prey Relationships. Estuaries, 7, 339-350. http://dx.doi.org/10.2307/1351618

[68] Fredriksen, S., Christie, H. and Saethre, B.A. (2005) Species Richness in Macroalgae and Macrofauna Assemblages on Fucus serratus L. (Phaeophyceae) and Zostera marina L. (Angiospermae) in Skagerrak, Norway. Marine Biology Research, 1, 2-19. http://dx.doi.org/10.1080/17451000510018953

[69] Do, V.T., de Montaudouin, X., Lavesque, N., Blanchet, H. and Guyard, H. (2011) Seagrass Colonization: Knock-On Effects on Zoobenthic Community, Populations and Individual Health. Estuarine Coastal and Shelf Science, 95, 458469. http://dx.doi.org/10.1016/j.ecss.2011.10.022

[70] Leopardas, V., Uy, W. and Nakaoka, M. (2014) Benthic Macrofaunal Assemblages in Multispecific Seagrass Meadows of the Southern Philippines: Variation among Vegetation Dominated by Different Seagrass Species. Journal of Experimental Marine Biology and Ecology, 457, 71-80. http://dx.doi.org/10.1016/j.jembe.2014.04.006

[71] Gravina, M.F., Ardizzone, A., Scaletta, F. and Chimenz, C. (1989) Descriptive Analysis and Classification of Benthic Communities in Some Mediterranean Coastal Lagoons (Central Italy). Marine Ecology, 10, 141-166. http://dx.doi.org/10.1111/j.1439-0485.1989.tb00071.x

[72] Butman, C.A. (1987) Larval Settlement of Soft-Sediment Invertebrates: The Spatial Scales of Pattern Explained by Active Habitat Selection and the Emerging Role of Hydrodynamical Processes. Oceanography and Marine BiologyAn Annual Review, 25, 113-165.

[73] Ólafsson, E.B., Peterson, C.H. and Ambrose, W.G. (1994) Does Recruitment Limitation Structure Populations and Communities of Macro-Invertebrates in Marine Soft Sediments: The Relative Significance of Pre- and Post-Settlement Processes? Oceanography and Marine Biology: An Annual Review, 32, 65-109.

[74] Snelgrove, P.V.R. and Butman, C.A. (1994) Animal-Sediment Relationships Revisited: Cause versus Effect. Oceanography and Marine Biology: An Annual Review, 32, 111-177.

[75] Bosselmann, A. (1991) Recruitment and Post Larval Growth of Some Macrozoobenthos Species in the German Bight. Meeresforschung, 33, 141-158. 
[76] Dale, V.H. and Beyeler, S.C. (2001) Challenges in the Development and Use of Ecological Indicators. Ecological Indicators, 1, 3-10. http://dx.doi.org/10.1016/S1470-160X(01)00003-6

[77] Dauvin, J.C. and Ruellet, T. (2007) Polychaete/Amphipod Ratio Revisited. Marine Pollution Bulletin, 55, $215-224$. http://dx.doi.org/10.1016/j.marpolbul.2006.08.045

[78] Simboura, N. (2004) Bentix Index vs Biotic Index in Monitoring: An Answer to Borja et al., 2003. Marine Pollution Bulletin, 48, 403-404. http://dx.doi.org/10.1016/j.marpolbul.2003.09.001

[79] Spencer, W., Rustigian-Romsos, H., Strittholt, J., Scheller, R., Zielinski, W. and Truex, R. (2011) Using Occupancy and Population Models to Assess Habitat Conservation Opportunities for an Isolated Carnivore Population. Biological conservation, 144, 788-803. http://dx.doi.org/10.1016/j.biocon.2010.10.027

[80] Bali, M. and Gueddari, M. (2011) Les chenaux de marée autour des îles de Kneiss, Tunisie: Sédimentologie et évolution. Hydrological Sciences Journal, 56, 498-506. http://dx.doi.org/10.1080/02626667.2011.563240 